\begin{abstract}
A $\mathbf{C}_{\text {ASE }} \mathbf{S}_{\text {TUd }}$
FOOD SCIENCE.

RESEARCH JOURNAL

e ISSN-2230-9403 Visit us : www.researchjournal.co.in

Volume 6 | Issue 2 | October, 2015 | 400-403

DOI : $10.15740 / \mathrm{HAS} / \mathrm{FSRJ} / 6.2 / 400-403$
\end{abstract}

\title{
Development of finger millet and flaxseed crackers
}

\author{
G.H. Athawale, A.D. Thorat and R.M. Shukla
}

Finger millet oftenly known as Ragi which is one of the most nutritious crop among the major cereal crops. Ragi is a coarse grain which is rich in fiber $(3.6 \mathrm{~g} / 100 \mathrm{~g})$ and calcium $(350 \mathrm{mg} / 100 \mathrm{~g})$. It has low Glycemic index which makes it a boon for people suffering from diabetes and obesity. It takes longer time to get digested and hence keeps check on the blood sugar levels and gives a feeling of fullness in the stomach whereas flax seeds are nutritionally high in alpha linoleic acid (ALA), an omega-3 fatty acid that is heart healthy and also a source of anti-inflammatory precursor molecules. They contain soluble and insoluble fibre, which helps to maintain normal cholesterol levels and promotes optimal bowel function. Different trials were done by combining finger millet and flaxseed with refined wheat flour to make nutritious product i.e., "Crackers", to finalize the formulation. Finalized product contained 11.04 per cent Poly-unsaturated fat fatty acid, 46.7 per cent dietary fibreand $70.3 \mathrm{mg} / 100 \mathrm{~g}$ calcium.

Key Words : Crackers, Calcium, Finger millet, Flaxseed, Omega-3 fatty acid, Wheat flour

How to cite this article : Athawale, G.K., Thorat, A.D. and Shukla, R.M. (2015). Development of finger millet and flaxseed crackers. Food Sci. Res. J., 6(2): 400-403.

A.D. THORAT AND R.M. SHUKLA, MIT College of Food Technology, PUNE (M.S.) INDIA 